\title{
MENINGKATKAN KEMAMPUAN SOSIAL EMOSIONAL ANAK MELALUI METODE ROLE PLAYING DI KELOMPOK BERMAIN
}

\author{
Refisi Duha ${ }^{1)}$, Ajeng Ayu Widiastuti ${ }^{2)}$ \\ 1)272014010@student.uksw.edu \\ 2) ajeng.widiastuti@staff.uksw.edu \\ Program Studi Pendidikan Guru PAUD
}

Fakultas Keguruan dan Ilmu Pendidikan Universitas Kristen Satya Wacana

\begin{abstract}
ABSTRAK
Role playing merupakan cara untuk penguasaan bahan pelajaran melalui pengembangan imajinasi dan penghayatan anak yang berperan sebagai subyek pembelajaran aktif. Kegiatan role playing yang dibahas dalam kajian ini merupakan salah satu upaya untuk meningkatkan kemampuan sosial emosional anak kelompok bermain. Untuk itu, tujuan dari penelitian ini adalah untuk meningkatkan kemampuan sosial-emosional anak melalui metode role playing di kelompok bermain Fransiskus Xaverius 78, Salatiga. Subjek penelitian ini adalah anak-anak kelompok bermain dengan usia 3-4 tahun yang berjumlah 12 anak, terdiri dari 6 perempuan dan 6 laki-laki. Objek penelitian adalah kemampuan sosial emosional anak melalui role playing. Jenis penelitian ini adalah Penelitian Tindakan Kelas (PTK) yang dilakukan dalam dua siklus dengan tiga kali pertemuan dalam satu siklus. Pada setiap siklus terdapat 3 tahap yaitu 1) perencanaan, 2) tindakan, dan 3) refleksi. Pengumpulan data dalam penelitian ini menggunakan observasi dan catatan lapangan. Adapun instrumen penelitian yang penulis gunakan adalah berpedoman pada Peraturan Menteri Pendidikan dan Kebudayaan (Permendikbud) Republik Indonesia nomor 137 tahun 2014 dalam observasi berupa lembar penilaian. Teknik analisis data yang digunakan adalah deskripstif kuantitatif dan deskriptif kualitatif. Hasil yang diperoleh dalam penelitian ini menunjukan bahwa ada peningkatan kemampuan sosial emosional anak kelompok bermain melalui metode role playing di KB/TK Fransiskus Xaverius 78 Salatiga. Hal ini dibuktikan dengan adanya peningkatan kemampuan sosial emosional anak dimana pada pratindakan sebesar $62.96 \%$, pada siklus I meningkat menjadi $75 \%$ dan pada siklus II meningkat menjadi $94.44 \%$.
\end{abstract}

Kata kunci : Metode Role Playing, Kemampuan Sosial Emosional Anak Kelompok Bermain.

\section{PENDAHULUAN}

Goleman (2006) menyatakan bahwa kematangan emosi seorang anak merupakan kunci keberhasilan dalam menjalin hubungan sosial. Kecakapan tersebut merupakan faktor utama dalam menunjang keberhasilan dalam pergaulan. Goleman (2006) juga menyebutkan bahwa salah satu kunci kecakapan sosial adalah seberapa baik atau buruk seseorang dalam mengungkapkan perasaan sehingga dapat diketahui bahwa kemampuan emosi besar pengaruhnya terhadap perkembangan sosial anak. Anak yang dapat mengen-dalikan diri dan mudah menunjukkan empati dan kasih sayang akan lebih mudah untuk bersosialisasi dengan orang-orang disekitarnya.

Melihat paparan paragraf diatas dapat diketahui bahwa perkembangan kemam- 
puan sosial-emosional pada anak usia dini penting untuk ditingkatkan, karena akan menentukan kehidupan anak selanjutnya, juga berbagai aspek perkembangan anak lainnya. Hurlock, mengatakan bahwa lima tahun kehidupan anak merupakan dasar perkembangan selanjutnya. Anak yang mengalami masa bahagia yaitu terpenuhinya segala kebutuhan baik fisik maupun psikis diawal, hal ini diramalkan anak akan mampu dan mudah untuk meningkatkan perkembangan selanjutnya (Suharyani, 2010).

Permendikbud nomor 137 tahun 2014 mengemukakan tingkat pencapaian perkembangan sosial-emosional anak kelompok bermain dengan rentang usia 3-4 tahun. Tahapan pencapaian perkem-bangan sosial-emosional untuk anak usia 3-4 tahun terbagi ke dalam tiga lingkup perkembangan yaitu : (1). Kesadaran diri, (2). Tanggung jawab diri dan orang lain, (3). Perilaku prososial.

Kesadaran diri, meliputi : mengikuti aktivitas dalam suatu kegiatan besar (misal: piknik), meniru apa yang dilakukan orang dewasa, bereaksi terhadap hal-hal yang tidak benar (marah bila diganggu), mengatakan perasaan secara verbal. Tanggung jawab diri dan orang lain, meliputi: mulai bisa mela-kukan buang air kecil tanpa bantuan, bersabar menunggu giliran, mulai menun-jukkan sikap toleran sehingga dapat bekerja dalam kelompok, mulai meng-hargai orang lain, mulai menunjukkan ekspresi menyesal ketika melakukan kesalahan. Kemudian perilaku prososial, meliputi: membangun kerjasama, memahami adanya perbedaan perasaan (teman takut, saya tidak), meminjam dan meminjamkan mainan.
Mengetahui betapa pentingnya meningkatkan kemampuan sosialemosional pada anak usia dini yang berada di jalur kelompok bermain, penulis memiliki ketertarikan dan keinginan untuk mengkaji lebih dalam lagi tentang kemampuan sosial-emosional pada anak usia dini, yaitu usia Kelompok Bermain 3-4 tahun di KB/TK Xaverius 78, Salatiga. Setelah melakukan observasi, penulis melihat bahwa anak Kelompok Bermain di Xaverius 78 dapat mengikuti dua perintah atau ajakan untuk berbaris dengan rapi, anak-anak memiliki hubungan yang baik dengan guru (akrab), anak-anak memberikan respon berupa jawaban ketika guru bertanya. Namun, penulis melihat masih banyak lagi aspek sosial emosional pada anak kelompok bermain yang perlu ditingkatkan seperti tidak dapat menunggu giliran atau mengantri, kurang dapat bekerjasama, tidak mau meminta maaf ketika bersalah, dan kurang menunjukan sikap untuk mendengarkan orang lain terutama guru.

Dengan adanya berbagai pemasalahan kemampuan sosial emosional pada anak Kelompok Bermain diatas penulis akan membatasi masalah dengan melihat aspek yang lebih Urgent untuk ditingkatkan yaitu hanya pada tanggung jawab diri dan orang lain yang meliputi sikap bersabar menunggu giliran, menghargai orang lain dan menunjukan ekspresi menyesal ketika melakukan kesalahan. Penulis juga tertarik untuk menggunakan salah satu metode untuk meningkatkan kemampuan sosialemosional anak di atas yaitu dengan menggunakan metode Role Playing. Mulyasa (Pujiati, 2013) tentang Peningkatan Ketrampilan Sosial Melalui Metode Bermain Peran (role playing), 
menjelaskan bahwa role playing adalah mengeksplorasi hubungan antar manusia dengan cara memperagakannya dan mendiskusikannya sehingga secara bersama-sama dapat mengeksplorasi perasaan, sikap, nilai, dan berbagai strategi pemecahan masalah. Biasanya anak didik memilih di antara beberapa topik yang diberikan kepada anak didik. Naskah pendek yang dibawakan biasanya sudah mengandung situasi permasalahan. Sesudah bermain peran berlangsung, masing-masing individu mendiskusikan bagaimana perasaan-perasaan mereka.

Dengan demikian tujuan dari penelitian ini adalah Untuk meningkatkan kemampuan sosial-emosional anak melalui metode role playing di KB/TK Fransiskus Xaverius 78, Salatiga.

\section{KAJIAN PUSTAKA}

Kajian tentang penggunaan metode role playing dalam meningkatkan kemampuan sosial-emosional pada anak memang bukan pertama kali dilakukan. Sejauh penelusuran yang dilakukan, peneliti menemukan beberapa hasil penelitian berkaitan dengan judul yang diangkat. Jurnal Pendidikan Usia Dini oleh Desti Pujiati dengan judul "Peningkatan Ketrampilan Sosial Melalui Metode Bermain Peran" tahun 2013. Jurnal ini merupakan penelitian tindakan (Action Research) menggunakan sepuluh tindakan dengan tema yang berbeda. Hasil akhir penelitian menunjukan bahwa penggunakan metode role playing terbukti efektif dan berdampak positif dalam meningkatkan ketrampilan sosial pada anak dimana terdapat peningkatan yang signifikan.

Hasil penelitian lain dari Wintari, dkk pada tahun 2015 dengan judul
'Penerapan Metode Bermain Peran (role playing) Berbantuan Media Konkret Dalam Meningkatkan Perkembangan Sosial Emosional Anak". Penelitian ini merupakan penelitian tindakan kelas (PTK). Hasil akhir dari penelitian ini adalah terjadi peningkatan perkembangan sosialemosional anak kelompok B TK Widya Bhakti Tua setelah diterapkan metode bermain peran berbantuan media konkret sebesar 23,43\%. Hal ini diketahui dari peningkatan rata-rata persentase anak siklus I sebesar 58,90\% yang berada pada kategori rendah menjadi sebesar $82,33 \%$ pada siklus II yang berada pada kategori tinggi.

Penelitian senada terdapat dalam penelitian Farida dan Muhammad Reza tahun 2014 dengan judul "Meningkatkan Kemampuan Sosial Emosional Anak Melalui Metode Bermain Peran Pada Kelompok Usia 3-4 Tahun Di PPT Cempaka Kota Surabaya". Penelitian ini merupakan penelitian tindakan kelas (Classroom Research) yang dirancang dalam siklus berulang. Berdasarkan hasil penelitian pada siklus I menunjukkan bahwa hasil kemampuan sosial emosional anak mencapai 50\%. Hasil persentase tersebut belum sesuai dengan kriteria tingkat pencapaian perkembangan anak yaitu 75\%, Oleh karena itu penelitian ini berlanjut pada siklus II. Hasil penelitian pada siklus II mengalami peningkatan sebesar 85\%. Berdasarkan hasil penelitian tersebut, dapat disimpulkan bahwa metode bermain peran dapat meningkatkan kemampuan sosial emosional kelompok anak usia 3-4 tahun di PPT Cempaka Surabaya. 


\section{METODE PENELITIAN}

Metode penelitian yang digunakan dalam penelitian ini adalah Penelitian Tindakan Kelas (PTK). Penelitian Tindakan Kelas merupakan suatu pencermatan terhadap kegiatan belajar berupa sebuah tindakan yang sengaja dimunculkan dan terjadi dalam sebuah kelas secara bersamaan (Arikunto dkk, 2009). Penelitian tindakan kelas ini dilakukan dalam dua siklus yaitu siklus I dan siklus II, masingmasing siklus dilakukan dalam tiga kali pertemuan. Menurut Arikunto (Ramdhani, 2014) penelitian tindakan kelas dilakukan dengan langkah-langkah berikut yaitu: 1) Tahap perencanaan, 2) Tahap Pelaksanaan, 3) Tahap Pengamatan, dan 4) Refleksi.

Subyek penelitian adalah anak-anak kelas kelompok bermain di KB Fransiskus Xaverius 78 Salatiga yang terdiri dari 12 anak, 6 anak laki-laki dan 6 anak perempuan dengan rentang usia 3-4 tahun.

\section{TEKNIK PENGUMPULAN DATA}

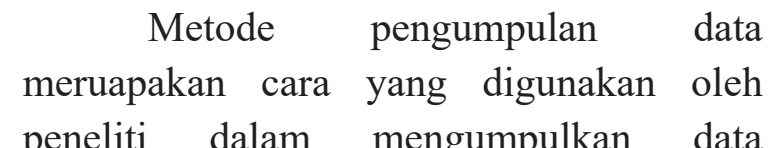
penelitiannya (Arikunto dalam Saputri, 2015). Adapun metode pengumpulan data yang digunakan dalam penelitian ini adalah menggunakan observasi atau pengamatan dan catatan lapangan. Observasi merupakan kegiatan pengamatan langsung terhadap pelaksanaan tindakan yang dilakukan. Tujuan pokok observasi adalah untuk mengetahui ada tidaknya perubahan yang terjadi dengan adanya pelaksanaan tindakan yang sedang berlangsung (Arikunto, 2010).

Menurut Arikunto (2006) observasi dapat dilakukan dengan dua cara yaitu observasi non sistematis yang dilakukan tidak dengan menggunakan instrumen pengamatan dan observasi sistematis yang dilakukan menggunakan pedoman sebagai instrumen penelitian. Teknik pengumpulan data dalam penelitian ini adalah menggunakan observasi sistematis dimana penulis membuat instrumen kegiatan dan indicator yang akan dimunculkan dalam penelitian.

Catatan lapangan adalah catatan tertulis tentang apa yang didengar, dilihat, dialami, dan dipikirkan dalam rangka pengumpulan data dan refleksi terhadap data dalam penelitian kualitatif (Arikunto, 2010). Catatan lapangan ini akan digunakan untuk mencatat semua temuan selama proses kegiatan pembelajaran atau yang diperoleh peneliti yang tidak teramati dalam pedoman observasi.

\section{INSTRUMEN PENELITIAN}

Instrumen penelitian adalah alat atau fasilitas yang digunakan oleh peneliti dalam mengumpulkan data agar pekerjaannya lebih mudah dan lebih baik dalam arti cermat, lengkap, dan sistematis sehingga lebih mudah diolah (Arikunto dalam Saputri, 2015). Pengisian instrumen penelitian dilakukan dengan memberikan tanda centang atau ceklis pada setiap tanda atau gejala yang muncul, sehingga peneliti menjadi tahu apakah metode dan kegiatan dalam meningkatkan kemampuan berbicara anak berhasil.

Sebelum penulis membuat instrumen penelitian terlebih dahulu penulis membuat kisi-kisi observasi. Kisi-kisi adalah sebuah tabel yang menunjukkan hubungan antara hal-hal yang disebutkan dalam baris dengan hal-hal yang disebutkan dalam kolom (Arikunto dalam Saputri, 2015). Pembuatan kisi-kisi berguna sebagai 
acuan dalam membuat instrumen karena dapat menunjukkan kaitan antara variabel dengan sumber data

\section{TEKNIK ANALISIS DATA}

Bogdan (dalam Saputri, 2015) mengemukakan bahwa analisis data merupakan penyusunan data yang diperoleh secara sistematis dari hasil observasi dan catatan lapangan sehingga dapat mudah dipahami dan temuannya dapat diinformasikan kepada orang lain. Selanjutnya, untuk mengetahui keefektifan suatu metode yang digunakan pada penelitian tindakan kelas ini digunakan analisis deskriptif kualitatif dan analisis deskriptif kuantitatif. Data kualitatif diperoleh dari penggunaan lembar observasi aktivitas siswa selama proses pembelajaran berlangsung. Analisis deskriptif kuantitatif dipergunakan untuk menentukan hasil yang diperoleh berdasarkan teknik skoring.

Tujuan analisis data dalam penelitian ini adalah untuk memperoleh kepastian, peningkatan dan perubahan sebagaimana yang diharapkan oleh penulis bukan untuk membuat generalisasi atau pengujian suatu teori. Untuk mengetahui tingkat keberhasilan penelitian tindakan kelas ini perlu dilakukan identifikasi pada skor yang telah diperoleh. Adapun rumus yang digunakan untuk mencari persentase (Sudijono dalam Saputri, 2015) dalam penelitian ini adalah sebagai berikut :

\begin{tabular}{|c|c|}
\hline & $\mathrm{F}$ \\
\hline $\mathrm{P}=$ & $\begin{array}{l}\text { X } 100 \% \\
\text { N }\end{array}$ \\
\hline
\end{tabular}

Gambar 3.2 Rumus Persentase
Keterangan:

$\mathrm{F}=$ Frekuensi yang dicari presentasinya

$\mathrm{N}=$ Number of cases (Jumlah frekuensi atau banyaknya individu)

$\mathrm{P}=$ Angka presentase

Langkah-langkah analisis data dalam penelitian ini yaitu:

1) Hasil observasi diberi skor (3, 2 atau 1) pada setiap masing-masing indikator keterampilan berbicara

2) Masing-masing indikator dihitung rata-rata kemampuan anak pada setiap pertemuan menggunakan rumus di atas (Purwanto dalam Ramadhani, 2014)

3) Persentase keberhasilan dihitung dengan cara skor pada setiap indicator dijumlah lalu dibagi dengan skor maksimal

4) Hasil persentase setiap indikator tersebut akan menghasilkan ratarata ketercapaian anak pada setiap pertemuannya

5) Analisis data diambil berdasarkan hasil persentase rata-rata kemampuan sosial emosional anak pada setiap pertemuan kemudian dipaparkan selisihnya

6) Hasil persentase setiap siklus nya diperjelas dalam bentuk tabel dan grafik.

Setelah melakukan pengumpulan data dengan lengkap, selanjutnya peneliti berusaha menyusun dan mengelompokkan data serta menyeleksi data yang ada dalam penelitian ini. Hal ini berfungsi sebagai jawaban atas rumusan masalah yang telah ditetapkan. Menurut Arikunto (Saputri, 2015), data yang diperoleh dalam penelitian 
ini diinterpretasikan dalam empat tingkatan

Interval $: 9-3=6$ yang disajikan dalam Tabel 7 berikut ini:

Nilai maksimal $: 3 \times 3=9$

Nilai minimal $\quad: 3 \times 1=3$

Tabel 6 Kriteria Keberhasilan Yang Dicapai

\begin{tabular}{|l|c|}
\hline \multicolumn{1}{|c|}{ Kriteria } & Nilai Skor \\
\hline Berkembang sangat baik (BSB) & $7-9$ \\
\hline Berkembang sesuai harapan (BSH) & $5-6$ \\
\hline Belum berkembang (BB) & $3-4$ \\
\hline
\end{tabular}

\section{HASIL DAN PEMBAHASAN}

Penelitian ini telah dilaksanakan di kelas Kelompok Bermain (KB) Fransiskus Xaverius 78 Salatiga yakni kelas yang diberikan perlakuan atau tindakan metode role playing. Hasil penelitian terdiri dari data pratindakan atau sebelum diberikan perlakuan metode role playing, hasil data siklus I dan hasil data siklus II.

Adapun hasil pratindakan kemampuan sosial emosional anak kelompok bermain di KB Fransiskus Xaverius 78 Salatiaga adalah sebagai berikut:

Tabel 1. Kemampuan Sosial Emosional Anak Pada Pratindakan

\begin{tabular}{|c|c|c|}
\hline Kriteria & Frekuensi & Persentase \\
\hline BSB & 4 & $33 \%$ \\
\hline BSH & 3 & $25 \%$ \\
\hline BB & 5 & $42 \%$ \\
\hline Total & 12 & 100 \\
\hline
\end{tabular}

Berdasarkan hasil data kemampuan sosial emosional anak saat pratindakan yang terdapat pada tabel 4.1, 4.2 dan 4.3 diketahui bahwa terdapat 4 anak atau 33\% yang mempunyai kemampuan sosial emosional yang berkembang sangat baik (BSB), kemudian 3 anak atau 25\% yang kemampuan sosial emosionalnya termasuk dalam kategori berkembang sesuai harapan (BSH) dan terdapat 5 anak atau 42\% yang kemampuan sosial emosionalnya belum berkembang (BB).
Setelah memperoleh data diatas maka penulis menindak lanjutkan pada pemberian perlakuan atau alur siklus yaitu siklus I. Pada siklus I penulis merancang kegiatan role playing yang akan dilakukan yaitu mulai dari menyusun rencana kegiatan harian, menyusun alur cerita untuk role playing, menyiapkan media role playing. Setiap pertemuan mencakup tiga langkah utama yaitu pembuakaan, inti dan penutup. Setelah menyelesaikan siklus I dengan tiga kali pertemuan penulis telah merangkum hasil data sebagai berikut : 
Tabel 2. Kemampuan Sosial Emosional Anak Setiap Pertemuan Pada Siklus I

\begin{tabular}{|l|l|l|l|l|l|l|}
\hline Kriteria & \multicolumn{2}{|l|}{ P1 } & P2 & P3 & \\
\hline & F & $\%$ & F & $\%$ & F & $\%$ \\
\hline BSB & 4 & 33 & 6 & 50 & 6 & 50 \\
\hline BSH & 5 & 42 & 4 & 33 & 4 & 33 \\
\hline BB & 3 & 25 & 2 & 17 & 2 & 17 \\
\hline Total & 12 & 100 & 12 & 100 & 12 & 100 \\
\hline
\end{tabular}

Pada tabel diatas dapat dilihat bahwa terjadi peningkatan kemampuan sosial emosional anak kelompok bermain setelah diberikan metode role playing. Namun peningkatan tersebut belum memenuhi standar pencapaian yang telah ditetapkan oleh penulis, dengan demikian akan dilanjutkan pada siklus II. Sebelum melanjutkan pada siklus II penulis melakukan beberapa refleksi atau evaluasi pada siklus I. Beberapa hal perlu dilakukan perbaikan terutama dari alur cerita role playing, media role playing, dan kemantapan penulis dalam mengendalikan kelas.

Siklus II kembali dilakukan seperti pada siklus I yang terdiri dari tiga kali pertemuan. Setelah melakukan kegiatan role playing sebanyak tiga kali, penulis merangkum hasil data dari pertemuan 1 sampai pertemuan ke-3. Adapun hasil data yang diperoleh adalah sebagai berikut :

Tabel 3. Kemampuan Sosial Emosional Anak Setiap Pertemuan Pada Siklus II

\begin{tabular}{|l|l|l|l|l|l|l|}
\hline Kriteria & P1 & \multicolumn{2}{l|}{ P2 } & P3 \\
\hline & F & $\%$ & F & $\%$ & F & $\%$ \\
\hline BSB & 8 & 67 & 9 & 75 & 12 & 100 \\
\hline BSH & 3 & 25 & 3 & 25 & 0 & 0 \\
\hline BB & 1 & 8 & & & & \\
\hline Total & 12 & 100 & 12 & 100 & 12 & 100 \\
\hline
\end{tabular}

Tabel 4. Perbandingan Kemampuan Sosial Emosional Anak Pada Pratindakan, Siklus I dan Siklus II

\begin{tabular}{|c|c|c|c|c|c|c|}
\hline Kriteria & \multicolumn{2}{|c|}{ Pratindakan } & \multicolumn{2}{c|}{ Siklus 1 } & \multicolumn{2}{c|}{ Siklus II } \\
\hline & F & Persentase & F & Persentase & F & Persentase \\
\hline BSB & 4 & $33 \%$ & 6 & $50 \%$ & 12 & 100 \\
\hline BSH & 3 & $25 \%$ & 4 & $33 \%$ & 0 & 0 \\
\hline BB & 5 & $42 \%$ & 2 & $17 \%$ & 0 & 0 \\
\hline Total & 12 & $100 \%$ & 12 & $100 \%$ & 12 & 100 \\
\hline
\end{tabular}

Tabel 5. Skor Total dan Persentase Kemampuan Sosial Emosional Anak Pratindakan Siklus I dan Siklus II

\begin{tabular}{|l|c|c|c|}
\hline \multicolumn{1}{|c|}{ Keterangan } & Pratindakan & Siklus I & Siklus II \\
\hline Skor Total & 68 & 81 & 102 \\
\hline & & & \\
\hline Persentase (\%) & 62.96 & 75 & 94.44 \\
\hline
\end{tabular}


Pada saat perbaikan yang dilakukan pada siklus II dapat dilihat bahwa peningkatan kemampuan sosial emosional anak melalui metode role playing terjadi peningkatan yang sangat signifikan dan sudah mencapai tingkat keberhasilan yang diharapkan dan telah ditetapkan. Hasil pengamatan pada tindakan siklus II, tentang peningkatan kemampuan sosial emosional anak kelompok bermain melalui metode role playing telah menunjukan bahwa hasil anak yang masuk kriteria berkembang sangat baik (BSB) telah mencapai lebih dari $80 \%$, sehingga kegiatan peningkatan kemampuan sosial emosional anak melalui metode role playing dihentikan.

Kemampuan sosial emosional anak secara keseluruhan sebelum tindakan atau prasiklus diperoleh hasil 4 anak atau 33\% dari jumalah semua anak yang memenuhi kriteria berkembang sangat baik (BSB), 3 anak atau 25\% dari semua jumlah anak yang memiliki kriteria berkembang sesuai harapan $(\mathrm{BSH})$ dan 5 anak atau 42\% dari jumlah semua anak yang memiliki kriteria belum berkembang. Pada kemampuan anak dapat menunggu giliran atau mengantri diperoleh data 5 anak atau $42 \%$ dari jumlah anak yang mempunyai kriteria berkembang sangat baik (BS), 4 anak atau 33\% anak yang memiliki kriteria berkembang sesuai harapan (BSH) dan 3 anak atau 25\% anak yang masuk kriteria belum berkembang (BB). Untuk kemampuan anak dapat mengharagai atau menunjukan sikap mau mendengarkan orang lain berbicara diperoleh data 4 anak atau 33\% anak yang memenuhi kriteria berkembang sangat baik (BSB), 2 anak atau $17 \%$ anak yang memiliki kriteria berkembang sesuai harapan (BSH), dan 6 anak atau 50\% anak yang masuk kriteria belum berkembang
(BB). Pada kemampuan anak dapat menunjukkan sikap minta maaf ketika berbuat salah diperoleh data 2 anak atau $17 \%$ dari semuan jumlah anak yang memenuhi kriteria berkembang sangat baik (BSB), 4 anak atau 33\% dari semua jumlah anak yang memiliki kriteria berkembang sesuai harapan (BSH), dan 6 anak atau 50\% dari semua jumlah anak yang masuk kriteria belum berkembang (BB).

Pada tindakan siklus I terjadi peningkatan namun belum memenuhi target keberhasilan yang ditetapkan. Dalam pelaksanaan siklus I terdapat banyak kendala yang memicu pelaksanaan tindakan menjadi kurang maksimal sehingga peningkatan yang diharapakan tidak terjadi. Hasil data yang diperoleh ketika pelaksanaan tindakan siklus I pada peningkatan kemampuan sosial emosional anak melalui metode role playing secara keseluruhan terdapat 6 anak atau 50\% dari jumlah anak yang memenuhi kriteria berkembang sangat baik (BSB), 4 anak atau $33 \%$ dari jumlah anak yang memilki kriteria berkembang sesuai harapan $(\mathrm{BSH})$ dan 2 anak atau $17 \%$ dari jumlah anak yang masuk kriteria belum berkembang (BB). Pada siklus I untuk kategori kemampuan anak bersabar menunggu giliran dengan mengantri diperoleh data 5 anak atau 42\% anak yang memenuhi kriteria berkembang sangat baik (BSB), 6 anak atau 50\% anak yang memiliki kriteria berkembang sesuai harapan (BSH) dan 1 anak atau 8\% yang masuk kriteria belum berkembang (BB). Untuk kategori anak menunjukan sikap mau mendengarkan orang lain berbicara diperoleh 4 anak atau 33\% anak yang memenuhi kriteria berkembang sangat baik (BSB), 2 anak atau 17\% anak yang memilki kriteria berkembang sesuai harapan $(\mathrm{BSH})$ 
dan 6 anak atau 50\% anak yang masih belum berkembang (BB). Untuk kategori anak dapat minta maaf ketika berbuat salah diperoleh 5 anak atau 42\% anak yang memenuhi kriteria berkembang sangat baik (BSB), 3 anak atau 25\% anak yang memiliki kriteria berkembang sesuai harapan $(\mathrm{BSH})$ dan 4 anak atau 33\% anak yang masuk kriteria belum berkembang (BB).

Berdasarkan pembahasan diatas setelah pelaksanaan tindakan siklus I dapat dilihat bahwa hasil yang diperoleh tidak jauh berbeda dengan hasil data saat pratindakan. Peningkatan kemampuan sosial emosional anak kelompok bermain melalui metode role playing setelah pelaksanaan tindakan siklus I telah meningkat namun belum memenuhi target indikator keberhasilan yang telah ditetapkan. Dengan adanya peningkatan kemampuan sosial emosional anak melalui metode role playing yang belum memenuhi target keberhasilan maka diperlukan adanya perbaikan tindakan pada siklus II yaitu penulis menggunakan suara yang lebih lantang ketika menjelaskan dan bercerita pada anak, penulis menggunakan bahasa atau kalimat yang sederhana sehingga dapat dipahami oleh anak, media yang digunakan diubah penampilannya dimana pada saat pelaksanaan tindakan siklus I penulis membuat atau menggambar sendiri namun pada saat siklus II penulis menggunakan gambar yang lebi menarik hasil dari pencarian di internet dan terkahir penulis mengatur posisi anak-anak yaitu dengan Line Up P-L-P-L. Selain itu, penulis juga memotivasi dan memberikan semangat untuk semua anak serta memberikan hadiah atau berupa Reward sebagai apresiasi untuk usaha anak dalam melakukan kegiatan role playing dengan baik.

Setelah perbaikan tindakan yang dilakukan pada siklus II terdapat hasil yang memuskan, dimana meningkatkan kemampuan sosial emosional pada anak kelompok bermain melalui metode role playing telah meningkat sesuai indikator keberhasilan yang telah ditetapkan. Adapun hasil kemampua sosial emosional anak secara keseluruhan yang diperoleh setelah melaksanakan siklus II adalah semua anak masuk dalam kriteria berkembang sangat baik (BSB) dengan skor total 102 dan persentase keberhasilan mencapai 94\%. Hasil yang telah diperoleh menunjukkan bahwa meningkatkan kemampuan sosial emosional anak kelompok bermain melalui metode role playing telah berhasil karena persentase keberhasilan mencapai 94\% dari target keberhasilan yang telah ditentukan yaitu $80 \%$.

Adapun hasil data untuk setiap kategori kemampuan sosial emosional anak adalah untuk kemampuan anak menunggu giliran dengan mengantri diperoleh data 11 anak atau 92\% dari jumlah anak yang memenuhi kriteria berkembang sangat baik (BSB), 1 anak atau 8\% dari jumlah anak yang memiliki kriteria berkembang sesuai harapan $(\mathrm{BSH})$, dan $0 \%$ atau tidak ada anak yang masuk kriteria belum berkembang (BB). Untuk kategori anak dapat menunjukan sikap mau mendengarkan orang lain berbicara diperoleh 10 anak atau $83 \%$ dari jumlah anak yang memenuhi kriteria berkembang sangat baik (BSB), 2 anak atau $17 \%$ dari jumlah anak yang berkembang sesuai harapan $(\mathrm{BSH})$ dan $0 \%$ atau tidak ada anak yang belum berkembang (BB). Untuk kategori anak dapat minta maaf ketika bersalah diperoleh 
10 anak atau 83\% dari jumlah anak yang memenuhi kriteria berkembang sangat baik (BSB), 1 anak atau 8\% dari jumlah anak yang berkembang sesuai harapan (BSH) dan 1 anak atau $8 \%$ dari jumlah anak yang masih belum berkembang (BB). Dari hasil diatas dapat dilihat bahwa masing-masing kategori kemampaun sosial emosionala anak meningkat dan telah mencapai 80\%.

Jadi, dengan dilaksankannya kegiatan role playing untuk meningkatkan kemampuan sosial emosional anak kelompok bermain di KB/TK Fransiskus 78 Salatiga yang melalui dua siklus telah berhasil dilakukan dan menunjukan hasil yang memuaskan bagi penulis, bagi anak dan juga bagi guru kelas.

\section{KESIMPULAN DAN SARAN}

\section{Kesimpulan}

Berdasarkan hasil dan pembahasan yang telah dilakukan, dapat ditarik satu kesimpulan bahwa kegiatan role playing dapat meningkatkan kemampuan sosial emosional anak kelompok bermain di KB/TK Fransiskus Xaverius 78 Salatiga. Hal ini dapat dibuktikan dengan peningkatan rata-rata kemampuan sosial emosional anak yang telah dicapai, dimana pada saat pratindakan diperoleh hasil $62.96 \%$, lalu pada siklus I meningkat menjadi 75\%, kemudian meningkat lagi menjadi $94.44 \%$ pada siklus II.

Kemampuan sosial emosional anak kelompok bermain mengalami peningkatan setelah penulis memberikan tindakan yang dilakukan melalui beberapa tahapan dan proses diantaranya adalah a) penulis menceritakan cerita b) kemudian anak diminta untuk melakukan role playing dengan mengikuti alur cerita yang diceritakan oleh penulis c) dan penulis memberikan motivasi pada anak-anak dan reward sebagai apresiasi untuk usaha anakanak dalam melakukan role playing dengan baik.

\section{Saran}

Adapun beberapa saran yang dapat diberikan oleh penulis berkaitan dengan penelitian ini adalah sebagai berikut:

a) Bagi Guru

Role playing dapat digunakan sebagai salah satu metode untuk membantu dan menstimulasi kemampuan sosial emosional anak kelompok bermain, diharapkan guru dapat lebih kreatif dalam mencipatkan pembelajaran untuk anak dan juga lebih menyusun kegiatan pembelajaran yang dapat membuat anak dapat berekspresi dan mengembangkan kemampuan dalam bersosialisasi serta matang dalam emosionalnya. Guru dapat menggunakan media pembelajaran yang lebih menarik bagi anak, dan menggunakan kalimat-kalimat sederhana sehingga mudah untuk dipahami oleh anak

b) Bagi Peneliti Selanjutnya

Diharapkan dapat menyusun skenario role playing yang lebih menarik dan jelas untuk anak, baik dari segi alur cerita, media dan rencana kegiatan pembelajarannya. Selain itu gunakan kalimat sederhana bagi anak dan juga menggunakan penjelasan kegiatan dalam bahasa yang singkat dan jelas agar lebih mudah dipahami oleh anak. 


\section{DAFTAR PUSTAKA}

Arikunto, Suharsimi. 2009. Penelitian Tindakan Kelas. Jakarta : PT. Bumi Aksara.

Farida, Farida dan Muhammad Reza. 2014. Meningkatkan Kemampuan Sosial Emosional Anak Melalui Metode Bermain Peran Pada Kelompok Usia 3-4 Tahun Di PPPT Cempaka Kota Surabaya. E-Journal UNESA. PAUD Teratai.

Ismawati, dkk. 2016. Penerapan Metode Role Playing Untuk Meningkatkan Hasil Belajar Siswa Pada Materi Hubungan Makhluk Hidup Dengan Lingkungannya. Jurnal Pena Ilmiah.

Mayar, Farida. 2013. Perkembangan Sosial Anak Usia Dini Sebagai Bibit Masa Depan Bangsa. Jurnal Al-Ta'lim, Jilid 1, Nomor 6.

Nurmalitasari, Femmi 2015.

Perkembangan Sosial Emosi Pada Anak Usia Prasekolah. Buletin Psikologi.

Pujiati, Desti. 2012. Peningkatan Keterampilan Sosial Melalui Metode Bermain Peran. Jakarta : Jurnal Pendidikan Usia Dini.

Pujiati, Desti. 2013. Peningkatan Keterampilan Sosial Melalui Metode Bermain Peran. Jurnal Pendidikan Anak Usia Dini.

Rachmawati, Ali Nugraha. 2013. Metode Pengembangan Sosial Emosional. Tangerang. : Universitas Terbuka. Rabiah dan Wayan Tamba. 2014. Pengaruh Bermain Peran Terhadap
Kemampuan Sosial Emosional Anak Usia 5-6 Tahun di TK Aisyiyah Bustanul Athfal 5 Mataram. Jurnal Paedagogy.

Sujiono, Bambang. 2005. Menu Pembelajaran Anak Usia Dini. Jakarta : Yayasan Citra Pendidikan Indonesia.

Siska, Yulia. 2011. Penerapan Metode Bermain Peran (Role Playing) Dalam Meningkatkan Keterampilan Sosial dan Keterampilan Berbicara Anak Usia Dini. Penelitian Tindakan Kelas. Edisi Khusus 2.

Susanti, Meila Herly. 2013. Upaya Meningkatkan Kecerdasan Sosial Emosional Anak Melalui Bermain Peran Pada TK A PAUD Taman Belia Candi Semarang Tahun Ajaran 2012/2013. Skripsi.

Wintari, Ni Luh Mira, dkk. 2015. Penerapan Metode Bermain Peran (Role Playing) Berbantuan Media Konkret Dalam Meningkatkan Perkembangan Sosial emosional Anak. E-Journal PG PAUD Universitas Pendidikan Ganesha.

Wulandari, Lathifa dan Sri Setyowati. 2009. Meningkatkan Kemampuan Sosial Emosional Anak Melalui Metode Bermain Peran Pada Kelompok B PPT Kuncup Harapan Surabaya. Universitas Negeri Semarang.

Wahyuni, Sri. 2014. Penerapan Metode Bermain peran Untuk Peningkatan Kemampuan Sosial Anak. Skripsi. 